\title{
ETNOMATEMATIKA PERMAINAN TRADISIONAL ANAK MAKASSAR SEBAGAI MEDIA PEMBELAJARAN GEOMETRI PADA SISWA SD
}

\author{
Titik Pitriani Muslimin ${ }^{1}$, Abdul Rahim ${ }^{2}$ \\ Universitas Sawerigading Makassar $^{1}$, UPT SPF SD Inpres Maccini Sombala ${ }^{2}$ \\ titikpitriani@gmail.com ${ }^{1}$, abdul0786rahim@gmail.com ${ }^{2}$
}

\begin{abstract}
Abstrak
Penelitian ini bertujuan untuk mengeksplorasi hubungan antara matematika dan budaya dengan fokus penelitian mengeksplorasi etnomatematika pada permainan tradisional anak suku Makassar. Penelitian ini merupakan penelitian kualitatif dengan pendekatan etnografi. Adapun Instrumen yang digunakan dalam penelitian ini adalah human instrument, di mana peneliti berhubungan langsung dengan penelitian dan berperan sebagai pengumpul data. Teknik pengumpulan data dilakukan melalui observasi, wawancara, dan dokumentasi. Berdasarkan hasil pengumpulan data penelitian diperoleh beberapa permainan tradisional anak Makassar yaitu dende', asing, cangke', dan gebok. Hasil penelitian ini menunjukkan bahwa permainan tradisional anak Makassar tersebut memuat konsep dasar geometri khususnya bangun datar dan bangun ruang. Arena dan alat pada permainan dende', asing, dan gebok memuat konsep bangun datar mulai dari jenisnya, sifatnya dan kekongruenan bangun datar. Sedangkan alat permainan pada permainan cangke' dan gebok memuat konsep bangun ruang. Permaina tradisional tersebut dapat dijadika media pembelajaran matematika di sekolah khususnya sekolah dasar agar pembeljaran lebih bermakna dan dapat meningkatkan minat belajar siswa.
\end{abstract}

Kata Kunci: Etnomatematika, Geometri, Permainan Tradisional Anak Makassar.

\section{A. Pendahuluan}

Kebudayaan lokal telah banyak dimanfaatkan sebagai inovasi dalam pembelajaran yakni dengan menjadikan budaya lokal sebagai sumber belajar yang kontekstual. Hal ini sejalan dengan kurikulum pendidikan saat ini yang menuntut adanya keterlibatan budaya dan perkembangan teknologi dalam Pendidikan (Prasetyani, 2018). Topik terkait budaya dalam pembelajaran khususnya dalam pembelajaran matematika dikenal sebagai etnomatematika (Nur, Sukestiyarno, \& Junaedi, I., 2019).

Etnomatematika diartikan sebagai antropologi budaya matematika (D'Ambrosio, 1985), dengan kata lain etnomatematika merupakan sebuah pendekatan yang mengkaji tentang hubungan antara budaya dan matematika serta 
mengekspresikan hubungan antara budaya dan matematika. Selain itu etnomatematika juga membedakan antara matematika di sekolah dengan matematika yang tertanam di dalam budaya yang terkadang jarang dijamah oleh sistem pembelajaran di sekolah (Turmudi, 2017).

Pelajaran matematika yang selalu menjadi momok menakutkan bagi siswa, menuntut pendidik agar dapat membuat inovasi-inovasi pembelajaran agar dapat menyajikan pembelajaran matematika yang menarik dan menyenangkan. Kenyataan di lapangan ditemukan masih banyak siswa yang merasa kesulitan mempelajari matematika. Selama ini umumnya siswa hanya bermodal menghafal rumus untuk menyelesaikan soal-soal matematika, tanpa memahami konsepnya(Muslimin,T.P, \& Taufiq, 2016). Hal ini disebabkan karena pembelajaran matematika oleh guru di sekolah terkadang tidak sejalan dengan perkembangan konsep-kosnep matematika dalam kehidupan sehari-hari. Hal inilah yang seringkali menimbulkan kebingungan pada siswa dan memicu kesulitan siswa dalam mengaitkan konsep matematika yang diperoleh di sekolah dengan konsep matematika di lingkungan sehari-harinya. Padahal menurut Abdullah (2017), sejatinya matematika tidak bisa lepas dari aktivitas keseharian hidup manusia, sehingga hal ini seharusnya membuat matematika menjadi lebih mudah dipahami oleh siswa. Oleh karena itu, pembelajaran matematika semestinya dapat menjadi jembatan penghubung antara matematika di kelas dan matematika dalam kehidupan sehari-hari (Pathuddin \& Raehana, 2019).

Untuk memudahkan siswa dalam memahami konsep matematika baik itu matematika di kelas maupun matematika dalam kehidupan sehari-hari salah satu inovasi yang dapat dimanfatkan adalah penerapan pendekatan etnomatematika. Berbagai hasil penelitian tentang penerapan etnomatematika melalui penggunaan sumber dan alat budaya berupa kerajinan, seni, cerita rakyat, nilai, moral, etika, dan filosofi yang berakar kuat pada sistem kepercayaan. Salah satu bidang kajian yang sering diteliti melalui pendekatan etnomatematika adalah bidang geometri. Menurut Isnawati \& Putra (2017), Geometri membahas tentang masalah dalam kehidupan sehari-hari baik berupa fenomena alam, bentuk-bentuk benda, serta kegiatan yang dilakukan dimana sebagian besar merupakan hasil dari geometri. Beberapa penelitian yang pernah dilakukan terkait geometri pada etnomatematika 
adalah penelitian tentang analisis makanan tradisional yang memiliki konsep bentuk geometri (Sari,Wahyuni, \& Larasati, 2020). Penelitian lainnya tentang aplikasi bangun datar segiempat pada candi Muaro Jambi (Hardiarti, 2017).

Dari beberapa strategi yang telah dieksplorasikan peneliti-peneliti sebelumnya, salah satu yang menarik bagi saya selaku peneliti yakni eksplorasi permainan tradisional khususnya dalam konsep matematika tingkat sekolah dasar. Berdasarkan hasil penelitian oleh Zaerani, Mardhiah, \& Suharti (2017) bahwa konsep dasar matematika yang disampaikan dengan menggunakan permainan secara kultural akan lebih mudah dipahami oleh siswa. Hal ini tentu saja tidak lepas dari ketertarikan siswa khususnya siswa SD dimana mereka masih dominan lebih menyukai berkumpul dan bermain bersama teman-temannya. Sesuai dengan buku Homo Ludens oleh Johan Huizinga dalam (Karimi, 2012) dikatakan bahwa manusia adalah makhluk yang suka bermain. Sehingga penerapan etnomatematika permainan tradisional dalam pembelajaran matematika ini akan dapat meningkatkan minat belajar siswa khususnya dalam pembelajaran matematika yang tentu saja akan berdampak positif juga pada hasil belajarnya. Sebab semakin tinggi minat siswa dalam mempelajari sesuatu maka akan semakin tinggi pula pengaruh yang diberikan pada hasil belajar siswa (Muslimin, T.P., 2016).

Observasi yang dilakukan pada beberapa siswa SDI Maccini Sombala yang merupakan salah satu sekolah dasar di kota Makassar, ditemukan bahwa siswa masih sering melakukan permainan tradisional. Beberapa permainan yang masih sering dilakukan diantaranya dende', asing, cangke' dan gebok. Jika diperhatikan bentuk-bentuk dari permainan tradisional tersebut mengandung konsep-konsep geometri yang menarik untuk dikaji lebih dalam.

Berdasarkan hal tersebut maka penulis merasa perlu untuk menggali dan mengeksplor lebih jauh tentang konsep-konsep geometri yang ada pada permainan tradisioanl anak. Sebab Pendekatan etnomatematika dalam permainan tradisional siswa sekolah dasar dapat digunakan sebagai penghubung antara materi matematika di sekolah dengan kehidupan sosial budaya siswa. Selain itu penerapan etnomatematika permainan tradisional dapat menjadi wadah dalam melestarikan budaya lokal dalam hal ini permainan tradisional bagi anak sebagai generasi 
penerus bangsa, dimana permainan tradisional sekarang ini mulai tergerus oleh perkembangan zaman.

\section{B. Metode Penelitian}

Metode penelitian menjelaskan rancangan kegiatan, ruang lingkup atau objek, bahan dan alat penelitian, tempat, teknik pengumpulan data, definisi operasional variable penelitian, dan teknik analisis.

Jenis penelitian yang digunakan dalam penelitian ini adalah penelitian kualitatif dengan pendekatan etnografi. Penelitian ini dilakukan dengan menggali informasi tentang permainan tradisional dan mengeksplorasi aktivitas etnomatematika dari permainan tradisional anak Makassar yakni dengan mengidentifikasi alat dan aturan permainan. Adapun permainan tradisional yang dimaksud adalah Dende', Asing, Cangke', dan Gebok. Instrument yang digunakan adalah human instrument, dalam hal ini peneliti berhubungan langsung dengan penelitian dan berperan sebagai pengumpul data, serta tidak dapat digantikan perannya.

Tahapan pelaksanaan penelitian ini terdiri dari enam tahapan berdasarkan prosedur siklus penelitian etnografi oleh Spradley dalam Emzir (2017) sebagai berikut:

1. Pemilihan proyek etnografi. Tahapan ini dimulai dengan memilih suatu proyek penelitan etnografi dengan mempertimbangkan ruang lingkup penelitian. Pada penelitian ini, penulis memilih melakukan penelitian di Kota Makassar yang merupakan salah satu daerah yang penduduknya sebagian besar adalah suku Makassar. Penulis juga membatasi ruang lingkup penelitian yaitu hanya mengeksplorasi aktivitas etnomatematika dari permainan tradisional anak tingkat sekolah dasar di Makassar .

2. Pertanyaan etnografi. Pada tahap ini, penulis mengajukan pertanyaan terhadap informan tentang hal-hal apa saja yang ingin penulis ketahui terkait dengan permainan tradisional anak Makassar. Adapun informan yang diwawancarai adalah anak-anak di SDI Maccini Sombala yang merupakan salah satu sekolah di kota Makassar yang mayoritas siswanya merupakan anak-anak dari suku Makassar. 
3. Pengumpulan data etnografi. Pada tahap ini, penulis mengumpulkan data melalui observasi. Data yang diperoleh berupa hasil pengamatan secara daring pada saat anak-anak bermain dan deskripsi hasil pertanyaan dan jawaban dari informan.

4. Pembuatan rekaman etnografi. Tahap ini dilakukan dengan membuat rekaman etnografi berupa pengambilan catatan dan dokumentasi. Foto-foto yang diambil pada tahap ini adalah foto-foto pada saat anak-anak bermain dan foto-foto alatalat permainan yang digunakan yang memiliki keterkaitan dengan bentukbentuk geometri.

5. Analisis data etnografi. Pada tahap ini, penulis melakukan analisis terhadap data-data lapangan yang telah dikumpulkan. Analisis yang dilakukan meliputi analisis domain dan analisis taksonomi. Analisis domain dilakukan untuk memperoleh gambaran yang umum dan menyeluruh tentang objek yang diteliti, dalam hal ini adalah permainan tradisional anak. Selain itu, melalui analisis domain juga ditentukan kategori serta pengelompokan data yang diperoleh berdasarkan kategori-kategori tersebut. Selanjutnya, analisis taksonomi dilakukan dengan cara menjabarkan kategori-kategori tersebut dengan lebih rinci berdasarkan konsep-konsep matematika yang terdapat pada permainan tradisional anak Makassar.

6. Penulisan sebuah etnografi. Pada tahap terakhir ini adalah menyampaikan atau memaparkan hasil-hasil penelitian yang berupa hasil observasi langsung maupun daring, wawancara, dan dokumentasi yang isinya tentang deskripsi keterkaitan antara konsep geometri dengan permainan tradisional anak Makassar.

Analisis data kualitatif penelitian ini mengacu pada Miles dan Huberman dalam (Sugiyono, 2014), yaitu reduction (reduksi data), display (penyajian data), conclusion/verification (kesimpulan/verifikasi).

\section{Hasil Dan Pembahasan}

1. Hasil penelitian

Berdasarkan hasil pengumpulan data penelitian dan hasil analisis data diperoleh bahwa alat dan bentuk permainan tradisional tersebut memiliki bentuk geometri berupa bangun datar dan bangun ruang. Dengan rincian sebagai berikut: 
a. Permainan Dende'

Permainan dende' atau dikenal juga dengan nama dende'-dende' merupakan salah satu permainan tradisional yang dimainkan oleh 2 atau lebih anak-anak. Alat yang dibutuhkan dalam permainan ini adalah sebuah bidang datar untuk menggambar kotak-kotak pijakan sebagai arena bermain, dan setiap anak yang bermain membutuhkan satu pelontar berupa batu kecil yang datar.
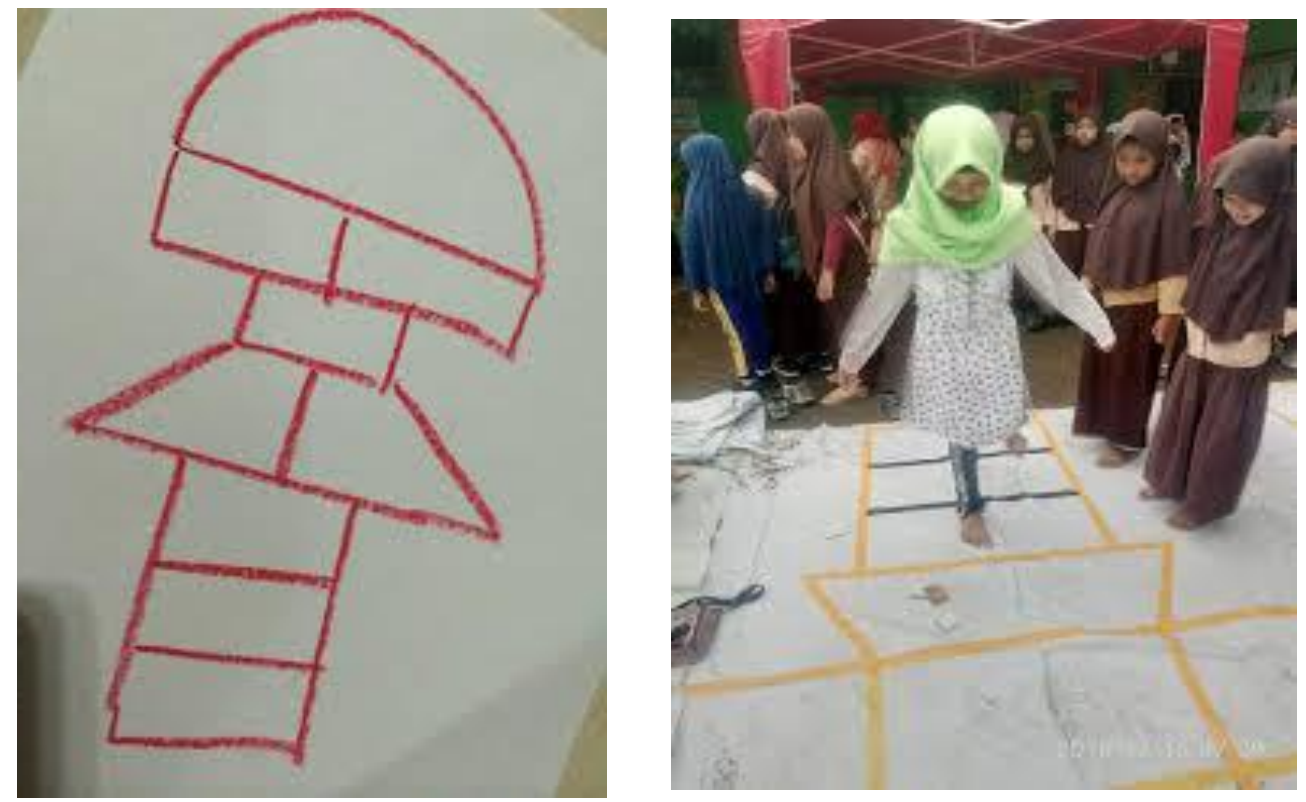

\section{Gambar 1. Permainan Dende’}

Berdasarkan hasil analisis pada gambar 1, diketahui bahwa pada arena bermain pada permainan dende' ini mengandung unsur geometri yakni bangun datar. Dibagian teratas yang disebut kepala,terdapat bentuk setengah lingkaran dan terdapat bentuk bangun persegi panjang. persegi, dan trapesium. Kemudian berdasarkan hasil wawancara pada beberapa anak bahwa pelontar yang digunakan berupa batu kecil yang datar dengan berbagai bentuk seperti bentuk persegi, persegi panjang, segitiga, bahkan uang logam yang berbentuk lingkaran pun dapat digunakan.

b. Permainan Asing

Permainan asing juga merupakan salah satu permainan tradisional anak Makassar. Permainan ini membutuhkan bidang datar yang cukup luas untuk membuat arena bermain dan permainan ini dimainkan sedikitnya 4 orang yang dibagi menjadi 2 tim. 


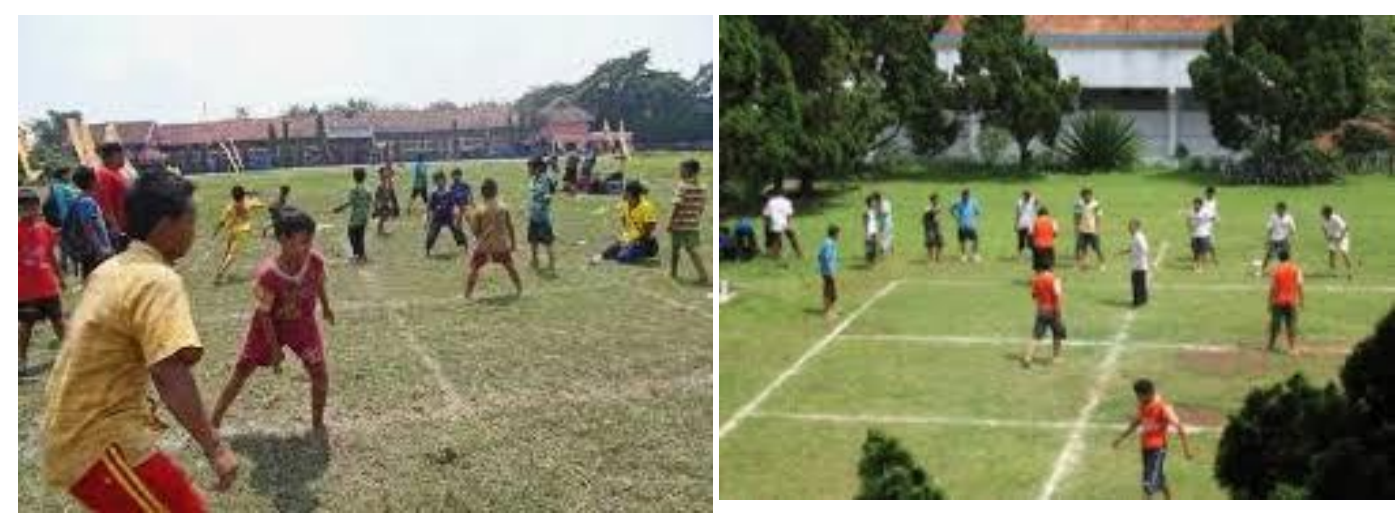

Gambar 2. Permainan asing

Berdasarkan hasil analisis pada gambar 2 diketahui bahwa arena bermain pada permainan asing berbentuk kotak-kotak persegi ataupun persegi panjang yang terdiri dari 6 kotak. Dimana ukuran dari setiap kotak permainan adalah sama besar. c. Permainan cangke'

Permainan cangke' merupakan permainan tradisional yang dimainkan oleh 2 kelompok anak, satu kelompok sebagai pemukul dan kelompok lainnya sebagai penangkap. Alat yang dibutuhkan dalam permainan ini adalah 2 buah stik yang terbuat dari potongan kayu, bambu, ataupun potongan pipa dengan ukuran yang berbeda dan sebuah lubang di tanah sebagai pijakan dari stik.
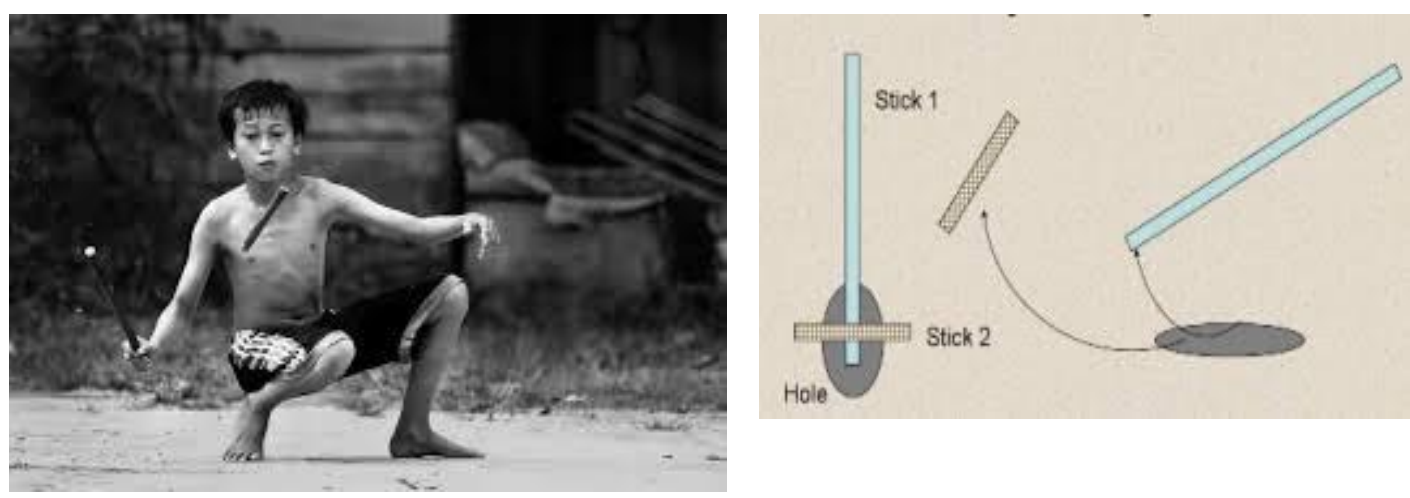

Gambar. 3 Permainan cangke'

Berdasarkan hasil analisis pada gambar 3 di atas diketahui stik yang digunakan dalam permainan cangke' berbentuk tabung dengan ukuran yang berbeda. Hal ini 
berarti alat dalam permainan cangke' memuat unsur geometri bangun ruang yakni tabung.

\section{d. Permainan gebok}

Permainan gebok juga merupakan salah satu permainan tradisional anak Makassar. Secara harfiah gebok berarti bola yang mengenai tubuh lawan. Permainan ini biasanya dimainkan oleh dua kelompok.
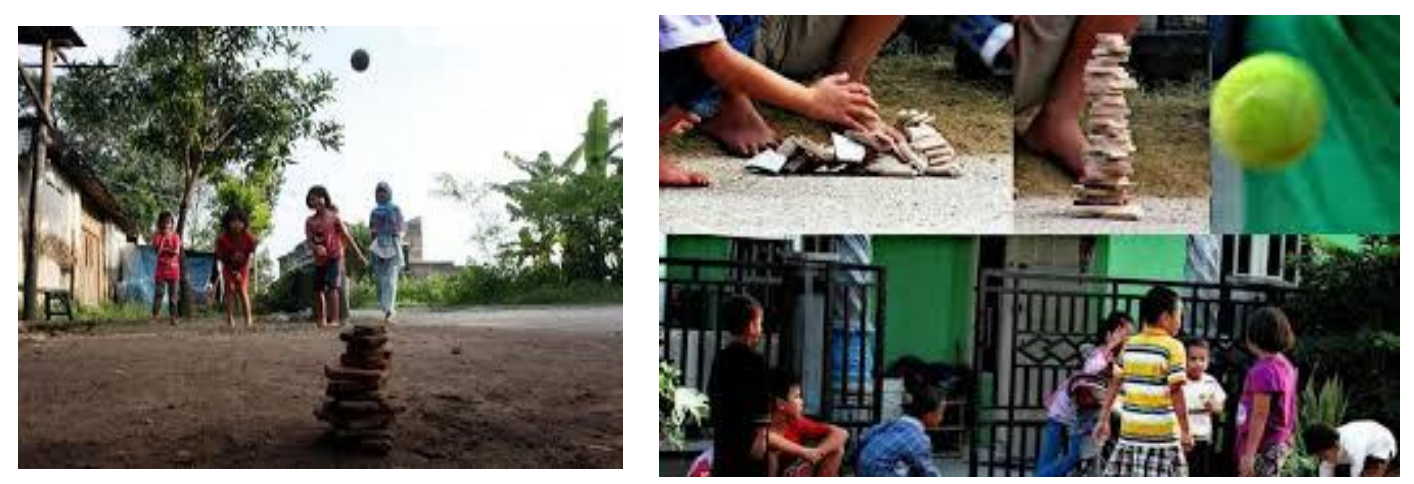

Gambar 4. Permainan gebok

Berdasarkan hasil analisis pada gambar 4 diatas diketahui bahwa alat yang digunakan dalam permainan gebok adalah sebuah bola kasti ataupun sesuatu yang dibentuk menyerupai bola, selain itu diperlukan batu-batu kecil dengan permukaan datar dengan berbagai bentuk ataupun dengan menggunakan pecahan-pecahan keramik . Bentuk alat yang dibutuhkan dalam permainan gebok ini mengandung konsep geometri yakni berbagai bentuk bangun datar serta bangun ruang yakni bola.

\section{Pembahasan}

Berdasarkan hasil penelitian di atas diketahui bahwa permainan tradisional anak Makassar merupakan salah satu budaya yang melekat dalam kehidupan masyarakat dan sangat dekat dengan aktivitas kehidupan siswa sehari-hari. Permainan tradisional mengandung konsep-konsep geometri khususnya konsep bangun datar dan bangun ruang. Sehingga permainan tradisional anak Makassar ini dapat dikembangkan menjadi sumber atau media pembelajaran bagi siswa khususnya siswa tingkat sekolah dasar, dalam menyajikan pembelajaran yang lebih konkret dan kontekstual. Sebab siswa SD lebih cenderung menyukai permainan daripada pembelajaran. Pada pembelajaran di sekolah, guru dapat meminta siswa 
mengamati alat-alat yang dibutuhkan dalam suatu permainan dan mengidentifikasi bentu-bentuk dari alat-alat yang dibutuhkan dalam permainan tersebut.

Adapun konsep geometri dalam permainan tradisional anak Makassar yang dibahas dalam penelitian ini yakni pertama permainan dende'. Dalam permainan dende' ditemukan konsep bangun datar pada arena permainannya diantaranya terdapat bangun datar persegi, persegi panjang, trapesium, dan setengah lingkarang.sedangkan untuk alat pelontar yang digunakan juga mengandung unsur bangun datar seperti lingkaran, segitiga, dan bentuk segiempat lainnya. Melalui permainan ini siwa dapat mengidentifikasi jenis dan sifat-sifat bangun datar. Kedua, permainan asing. Dalam permainan ini ditemukan konsep bangun datar yakni persegi dan persegi panjang pada arena permainan. Melalui permainan ini siswa dapat mengidentifikasi perbedaan anatara persegi dan persegi Panjang serta menentukan kekongruenan dari bangun tersebut. Ketiga, permainan cangke'. Dalam permainan cangke' ditemukan konsep bangun ruang pada alat permainannya yakni stik berbentuk tabung dengan ukuran yang berbeda. Melalui permainan ini siswa dapat mengidentifikasi sifat-sifat dari tabung serta bagaimana cara pengukurannya. Keempat, permainan gebok. Dalam permainan gebok ditemukan konsep geometri tentang bangun datar dan bangun ruang yakni bola pada alat permainannya. Melalui permainan ini, siswa dapat diarahkan untuk mengidentifikasi jenis-jenis bangun datar yang digunakan, selain itu siswa pula dapat mengidentifikasikan sifat-sifat dari bangun rung yakni bola.

Dengan menggunakan permainan tradisional anak Makassar sebagai media pembelajaran, siswa diharapkan dapat termotivasi dalam pembelajaran matematika dan lebih mudah memahami konsep-konsep matematika terutama konsep dasar geometri.

\section{Kesimpulan}

Berdasarkan hasil penelitian, dapat disimpulkan bahwa terdapat unsur etnomatematika pada permainan tradisional anak Makassar yaitu konsep dasar geometri yang terdiri dari bangun datar dan bangun ruang. Terdapat empat jenis permainan tradisional Makassar yang mengandung konsep geometri yaitu permainan dende', asing, cangke' dan gebok. Konsep bangun datar ditemukan dalam arena permainan dende' dan asing. Selain itu konsep bangun datar juga 
ditemukan dalam alat yang digunakan dalam permainan dende', dan gebok. Selanjutnya konsep bangun ruang yakni tabung ditemukan pada alat permainan cangke'dan bola pada alat permainan gebok. Selain itu terdapat konsep kekongruenan bangun datar dalam permainan asing. Guru dapat memanfaatkan permainan tradisional tersebut sebagai media belajar matematika yang lebih konkret dan inovatif, serta dapat digunakan untuk meningkatkan proses berpikir kritis siswa. Dengan demikian, pembelajaran matematika akan menjadi lebih bermakna karena sumber belajar berasal dari lingkungan sekitar siswa.

\section{Daftar Pustaka}

Abdullah, A. S. (2017). Ethnomathematics in Perspective of Sundanese Culture. Journal on Mathematics Education, 8(1), 1-16.

d'Ambrosio, U. (1985). Ethnomathematics and its place in the history and pedagogy of mathematics. For the learning of Mathematics, 5(1), 44-48.

Emzir. (2017). Metodologi penelitian pendidikan kuantitatif \& kualitatif. Jakarta: PT. RajaGrafindo Persada

Hardiarti, S. (2017). Etnomatematika: Aplikasi Bangun Datar Segiempat pada Candi Muaro Jambi. Aksioma, 8(2), 99-110.

Isnawati, L. Z., \& Putra, F. G. (2017). Analisis unsur matematika pada motif sulam usus. NUMERICAL: Jurnal Matematika dan Pendidikan Matematika, 8796.

Karimi, A. F. (2012). Think Different; Jejak Pikir Reflektif Seputar Intelektualitas, Humanitas, dan Religiusitas. Ahmad Faizin Karimi.

Muslimin, T. P. (2016). Pengaruh Metode Recollection Smart Teaching (RST) Terhadap Minat Belajar Mahasiswa Melalui Lesson Study. Prosiding, 2(1).

Muslimin, T. P., \& Taufiq, T. (2016). Penerapan Model Pembelajaran Kooperatif tipe Numbered Heads Together (NHT) terhadap Peningkatan Hasil Belajar Siswa Kelas VIIIc SMP N 3 Palopo. Pedagogy: Jurnal Pendidikan Matematika, 1(1).

Nur, A. S., Sukestiyarno, Y. L., \& Junaedi, I. (2019). Etnomatematika dalam Perspektif Problematika Pembelajaran Matematika: Tantangan pada Siswa Indigenous. In Prosiding Seminar Nasional Pascasarjana (PROSNAMPAS) (Vol. 2, No. 1, pp. 90-96). 
Pathuddin, H., \& Raehana, S. (2019). ETNOMATEMATIKA: MAKANAN TRADISIONAL BUGIS SEBAGAI SUMBER BELAJAR MATEMATIKA. MaPan: Jurnal Matematika dan Pembelajaran, 7(2), 307-327.

Prasetyani, W. (2018). Peran Etnomatika Jawa Sebagai Pendukung Literasi Matematis Siswa. Purwokerto: UMP

Sari, N. R., Wahyuni, P., \& Larasati, A. (2020, May). Analisis Makanan Tradisional Dalam Perspektif Etnomatematika Sebagai Pendukung Literasi dan Sumber Belajar Matematika. In Prosiding Seminar Pendidikan Matematika dan Matematika (Vol. 2).

Sugiyono. (2014). Metode Penelitian Pendidikan: Pendekatan Kualitatif, $R \& D$. Bandung: Alfabeta

Turmudi, T. (2017, September). Ethnomathematics: Apa Mengapa dan Bagaimana Implementasi dalam Pembelajaran Matematika di Kelas. In SENATIK 2017.

Zaerani, S. Mardhiah., \& Suharti. 2017."Pengaruh Penguasaan Konsep Teorema Pythagoras terhadap Kemampuan Menyelesaikan Soal-Soal Bangun Ruang Sisi Datar pada Siswa Kelas VIII MTS Negeri Balang-Balang”. MaPan: Jurnal Matematika dan Pembelajaran, 5(2), 279-292. 